\title{
Enhancing Content Knowledge in Essay Writing Classes: A Multimedia Package for Iranian EFL Learners
}

\author{
Marziyeh Tahmouresi Majelan (Corresponding author) \\ English Language Faculty, Islamic Azad University, Tehran North Branch \\ E-mail: marziyeh105@yahoo.com
}

Doi:10.7575/aiac.alls.v.5n.2p.87

URL: http://dx.doi.org/10.7575/aiac.alls.v.5n.2p.87
Received: $15 / 02 / 2014$

Accepted: 30/03/2014

\begin{abstract}
The main objective of this study was to investigate empirically if promoting a multimedia package enhances content knowledge in essay writing of 80 junior English translation students at a University in Karaj, Iran; plus, whether the learners' writing content improve due to the presence of the multimedia package or not. The multimedia was considered to be a $\mathrm{CD}$, containing recordings both in first language ( $\mathrm{L} 1=$ Farsi) and in second language ( $22=$ English) along with manipulative and task-based activities. A homogenizing test, the pre-posttests, and the material in a form of a CD (treatment including forty of the most common TOEFL essays both in L1 and L2 plus manipulative tasks to fulfill) provided by the researcher, were the instruments in the study. After 14 weeks, both the experimental and control groups sat for the posttest with exactly the same characteristics of pretest except for the topics. When the collected data was analyzed, a mean difference of t-test along with a paired t-test showed a significant difference between the performance of the control and the experimental groups, regarding the content. Consequently, the statistics proved that enhancing content knowledge by means of a multimedia package containing recordings plus manipulative and task-based activities would improve students' writing ability while the control group in which a current traditional rhetoric approach was used, the placebo, did not show any statistically significant improvement regarding content.
\end{abstract}

Keywords: writing skill, task-based activities, content knowledge, t-test

\section{Introduction}

Writing is a good means for monitoring the process of learning as well as acquisition if the students themselves are responsible for their own learning. Writing transfers the learned information to the long-term memory and therefore, fosters the attention to form and function as well as the communication (Chastain, 1988)

Most of the studies conducted in writing, however, were neglecting the important goal of writing as a means of communication and rather focusing just on the form, i.e. they focused on either organization or mechanics of writing; therefore, they ignored the content. Meanwhile, it is assumed that the lack of familiarity or poor familiarity with content in writing could affect the validity of the writing tests.

Unfortunately, content has always been neglected because of this wrong belief that it does not matter what you write about as long as it conforms to an accepted rhetorical model. Therefore, content of a writing course takes a back seat to practice as long as teachers consider writing as one of the four skills which should be used to test if other skills have been mastered. (Chastain, 1988).

In this study, however, in order to answer these questions: Does providing learners with a multimedia package, a $\mathrm{CD}$ containing both L1 and L2 manipulative and task-based activities, enhance content knowledge in essay writing of the intermediate Iranian EFL learners? Regarding content, does the writing ability of the intermediate Iranian EFL learners progress in the presence of the multimedia package? the greatest effort has been on the writing skill itself and since the aim of the study was students were supposed to use the multimedia at home to improve themselves and to self-invest just as Rutherford and Sharwood-Smith (1988) stated (e.g., through giving learners responsibility for making decisions and through encouraging them to make discoveries about the language for themselves). Learners must be ready to acquire the points being taught' (both in terms of linguistic, developmental readiness and of psychological readiness too Meisel et al., 1981; Pienemann, 1985).The researcher believe as students involve in some activities including listening to various audio texts, discussing their ideas, listening to their classmates, and writing about various topics, their content knowledge grows along with vocabulary and linguistic forms, which are as a result of the enhancement of content knowledge. As a matter of fact that could prove the idea that familiarity with the content area can help learners perform better at least if they encounter familiar topics.

\section{Review of literature}

Some researchers such as Hyland (2002)advocate looking beyond the more traditional applied linguistics view of text as autonomous objects; that is, teachers should not restrict themselves to the 'surface structures rather to see texts as attempts to communicate with others' which is good for raters and judges to consider while scoring written texts. The majority of research over the last 15 years indicates that raters tend to be more concerned about content and 
organization in writing than sentence structure and mechanics (Huot, 1990). As a result, familiarity with content is of important significance since teachers evaluate writings for the level of understanding or content knowledge. Weir (2005) also pointed out establishing theory-based validity in writing is concerned with evaluating the activation of executive resources and extensive processes promoted by the task. Executive resources involve linguistic resources and content knowledge. Content knowledge may already be possessed by the candidate through developed schemata or might be available in information supplied in task input.

According to Chastain (1988), in addition to interesting topics and necessary instruction which are provided by the teacher, teachers should give some information needed to write about the topic because students need to have somewhat of starting-point or triggering means to begin writing.

According to researches carried out in the past few years, teachers' contribution to students has been suggested through different methods in teaching different subjects or language skills:

\subsection{Modeling}

Helping students to generate ideas for writing and to organize their ideas effectively is a key component in all writing activities (Vinson, 1980).The assumption that novice writers will learn from seeing what others have done and from imitating those forms and techniques is an essential factor for teachers to decide to use models in the classrooms (Hillocks, 1986). Models can be used as examples of different types of writing to help students understand the characteristics of good writing and how to improve their own writing as in a study conducted by Graham and Perin (2007).

Considering content as one of the characteristics of a good writing, preliminary findings have provided evidence that familiarity with subject matter can compensate for inferior linguistic proficiency (Alderson \& Urquhart, 1985). By reading different writing models on the same topic, students can develop proper background knowledge. However, only some previous studies have addressed the effect of writers' background knowledge on writing performance, and none have considered content regarding writing skill. On the contrary, writing has mainly been utilized as an effective tool to enhance students' learning of content material.

\subsection{Learning Content Material}

Writing can be used as a device for learning content material. Nevertheless, most of the studies carried out in this regard were dealing content as it is dealt with in content-based language teaching approach like the study by Graham and Perin (2006) in which writing-to-learn was equally effective for all content areas (social studies, math, and science).As a matter of fact, writing was applied as a contributing means for learning other subject areas, which meant not focusing on the writing skill itself.

\subsection{Computer-assisted language learning}

Applying CALL materials is another method used by teachers to facilitate the language learning process in all the skills including writing. Computer-assisted language learning (CALL) materials are student-centered accelerated learning materials, which promote self-paced accelerated learning (Davies and Higgins, 1982). Multimedia, as one of CALL's materials, can then offer the authentic English materials conveniently and accurately in both visual and audio ways (Howard, 1983). Acha (2009) suggested that multimedia can provide a large amount of instructional information to the students for the purpose of English writing skill. However, some researchers believe that most teachers depend on multimedia teaching method excessively and neglect its auxiliary teaching function. According to Johnstone \& Milne (1995), teachers are always the facilitator of the whole class, whether they are teaching in the traditional classroom or in the multimedia classroom. Consequently, using multimedia in the classrooms does not mean that teachers are supposed to be substituted by multimedia.

Considering the importance of content in evaluation of writing products and the tried-and-true usage of multimedia in current teaching and learning environment, in the present study, we sought to investigate the effects of a multimedia package, a take-home CD on the writing content of students. We compared the writing content of students using the multimedia package with other students who are only exposed to current-traditional rhetoric approach, in which the application of multimedia does not exist and there is no extra focus on the students' writing content.

\section{Method}

\subsection{Participants}

Participants involved in this study were 80 English Translation students, studying in the fifth semester at a University in Karaj, Iran. The L1 of these students, studying in coeducational classes, was Farsi. The number of female students in both experimental $(n=40)$ and control $(n=40)$ groups exceeded the male ones, almost $3: 1$; whereas, all had already passed the Advanced Writing course and were participating in Essay Writing course classes.

\subsection{Instrumentation}

The instruments employed in this study included a PBT test used as the homogenizing test. To investigate the effectiveness of the research method under question, the pretest and posttest topics were excerpted from www.ets.org, which is the official website of TOEFL. Jacobs' et al. (1981) writing criteria called "ESL Composition Scoring Profile" was utilized as the rating scale by two raters for scoring the written products in pre and posttests. Both raters used Jacobs et. al. s' writing template (1981) called "ESL Composition Scoring Profile" to score the writings regarding the content. Jacob's scale is divided into five major writing components: content, organization, vocabulary, language, and 
mechanics. A writing evaluation instrument is said to have content validity when “. . . it evaluates writers' performance on the kind of writing tasks they are normally required to do in the classroom" (Jacobs et al., 1981, p. 74). Jacob's writing scale has content validity since the criteria outlined evaluate the performance of EFL/ ESL students' different types of expository writing which are tasks they perform in the foreign language classroom.

\subsubsection{Inter-rater reliability for pretest}

After the data was collected from the pretest, two raters scored them. Since studies should consistently report inter-rater reliability, even if only on a portion of the data, some parts of the data collected from the pretest were randomly selected, random essays of 80 , and then inter-rater reliability was calculated, using Pearson's Product-moment coefficient of correlation(r). An inter-rater reliability of .80 represents that there is a high degree of consistency in the judgment of the raters in the pretest. It has been represented in the Table 1.

Table 1. Inter-rater reliability for the pretest

\begin{tabular}{ccc}
\hline & & RAT2 \\
\hline \multirow{2}{*}{ RAT1 } & Pearson Correlation & $.804^{\mathrm{a}}$ \\
\cline { 2 - 3 } & Sig. (2-tailed) & .000 \\
\cline { 2 - 3 } & $\mathrm{N}$ & 80
\end{tabular}

${ }^{a}$ Correlation is significant at the 0.05 level (2-tailed)

\subsubsection{Inter-rater reliability for posttest}

An inter-rater reliability of .86 represents that there is a high degree of consistency in the judgment of the raters in the posttest. It has been represented in Table 2. It should be noted that, like pretest, from 160 essays of both experimental and control posttest results, only 80 have been randomly chosen to test the inter-rater reliability.

Table 2. Inter-rater reliability for the posttest

\begin{tabular}{ccc}
\hline & & RAT2 \\
\hline \multirow{2}{*}{ RAT1 } & Pearson Correlation & $.865^{\mathrm{b}}$ \\
\cline { 2 - 3 } & $\mathrm{N}$ & .000 \\
\hline${ }^{\mathrm{b}}$ Correlation is (2-tailed) & 80 \\
\hline
\end{tabular}

\subsection{Material}

The treatment which was in the form of a multimedia package (a CD containing both related audio and written contents in L1and L2), was prepared by the researcher herself. The CD consisted of audio and written parts including40 of the most common TOEFL topics, which were selected from www.ets.org. It is good to mention that after interviewing the participants, the researcher selected the topics according to the frequency of occurrence in the writing part of IELTS exams and their level of difficulty. During the interview session, the participants were required to provide three blue prints or supporting ideas for each 60 topics, excerpted from the TOEFL official web site. The result showed that approximately all the students had problems providing acceptable content for forty of those sixty topics. As a result, they were selected as the topics of the content materials provided here.

For the audio section of the material, 80 English five-paragraph essays with the same topics as the written section were selected as models to be recorded both in L1 and L2. The texts of the English audio part were excerpted from Sample Essays for the TOEFL Writing Test (TWE)-Answer to all Essay Questions book published in 2004.However, for the L1audio part, the remained 40 English essays which were selected from the official website of TOEFL were firstly translated by the researcher into Farsi (L1) and then they were recorded on the same CD.

The written section of the CD contained two sets of drills. The topics were divided into two groups of 20 . The first 20 topics were written along with their three blue prints in the multiple choice format with three written options (A, B, and C), one of which was irrelevant and participants were supposed to find. The students were also expected to fill in the last option (D), which was left blank, with one relevant blue print. The second 20 topics were followed by their relevant five-paragraph essays, all of which were extracted from How to Prepare for TOEFL Essays by Abbas Zahedi (2006). The topic sentences for the second, third and fourth paragraphs were missing so that students could jot them down according to the content of body paragraphs and the whole texts. 


\subsection{Procedure}

In the present study, administering the PBT test as homogenizing test, pretest, working with the multimedia package-which was listening to the audio section of the $\mathrm{CD}$ and working on the written section of the $\mathrm{CD}$ (including two sets of drills)-- all spanned 14 weeks. The initial100 junior participants attended the essay writing course classes which were held once a week. In the very first session, the standardized PBT TOEFL test was administered to test the homogeneity of the students, one class $(\mathrm{n}=52)$ and the other one $(\mathrm{n}=48)$.

After the homogeneizing test was applied and the gained data were analyzed, from among 100 students involved, only 80 were selected as the participants of this study since they fell within about one standard deviation above and below the mean. The outliers were eliminated from the data analysis of the study. They might have benefited from the treatment, though. In the second session, both classes took the pretest to ensure that at the beginning of the study, both groups were almost at the same level of proficiency regarding the element under investigation, the writing content. The test consisted of two writing topics for which the testees were demanded to write two five-paragraph essays within the time allocation of 60 minutes and the length of at least 150 words. The topics kept the same in both experimental and control groups. The whole papers were scored once by two different raters. The raters were required to score each essay based on the students' writing content using Jacobs et al.'s writing template (1981) called "ESL Composition Scoring Profile". Subjectivity of the scoring was decreased by considering the mean of the two marks as the testees' mark.

Both experimental and control groups were taught the mechanics of writing and paragraph patterns at an advanced level (current-traditional rhetoric approach) within 12 sessions of the university semester. They got familiar with different types of essays like cause and effect, comparison, contrast, explanation, etc. The control group was taught just the mechanics of writing and paragraph patterns at an advanced level (current-traditional rhetoric approach). It was concerned only with correctness. The simple injunction was to "select, narrow, and amplify". They were given no extra practice on the content area of their writing, that is, if they lacked certain content for an essay, they could not provide relevant information or write appropriately, regarding the content, there were no feedbacks in this regard. At home, they had to write a five-paragraph essay on a given topic for each session. The teacher collected the essays and scored them for the following session. On the other hand, for the experimental class, the treatment, conducted along with the currenttraditional rhetoric approach, commenced from the third session. Students were supposed to work on the material both at home and in the class.

The students in the experimental class were expected to work on the drills and listen to the audio texts of almost three to four topics per week. The writing drills which were of two types were entirely given to students both on a paper and on the same audio CD so that they could work on them at home and bring them to the class. Within the classroom, they discussed and compared their answers with their classmates. It should be mentioned that since the topics of the written drills were the same as the forty Persian and English audio parts, the students were not allowed duplicate the same blue prints and topic sentences of the audio part in the drill part so that they could develop a larger amount of knowledge regarding content. At the end of the procedure, to validate the comparison, both experimental and control groups took the same posttest exams, which were two five-paragraph essays on the given topics with the length of 150 words and within the time span of 60 minutes.

\section{Results}

\subsection{Homogenizing Test}

Several sets of statistical analysis were performed in order to find the answer to the following research question:

Q1) Does providing learners with a multimedia package-- a CD containing both L1 and L2 recordings plus manipulative and task-based activities-- enhance content knowledge in essay writing of the intermediate Iranian EFL learners?

Q2) Regarding content, does the writing ability of the intermediate Iranian EFL learners progress in the presence of the multimedia package?

The result of those analyses are reported and discussed below. Table 3 shows the statistic results of the homogenizing test. The mean and standard deviation of the general proficiency test turned out to be 51.28 and 12.80respectively. As the table shows the skewness value turned out to be -.132 and the standard error of skewness was .241. The division of the statistic of skewness by standard error of skewness appears to be .547 . Since this figure fell within -1.96 and +1.96 , it was concluded that the distribution was normal.

Table 3. Descriptive statistics of the homogenizing test

\begin{tabular}{ccccccccc}
\hline $\mathrm{N}$ & Minimum & Maximum & Mean & $\begin{array}{c}\text { Std. Error of } \\
\text { Mean }\end{array}$ & $\begin{array}{c}\text { Std. } \\
\text { Deviation }\end{array}$ & Variance & Skewness & Std. Error of \\
Skewness
\end{tabular}

Figure 1. shows the normal distribution after the homogenizing test result was analyzed. 


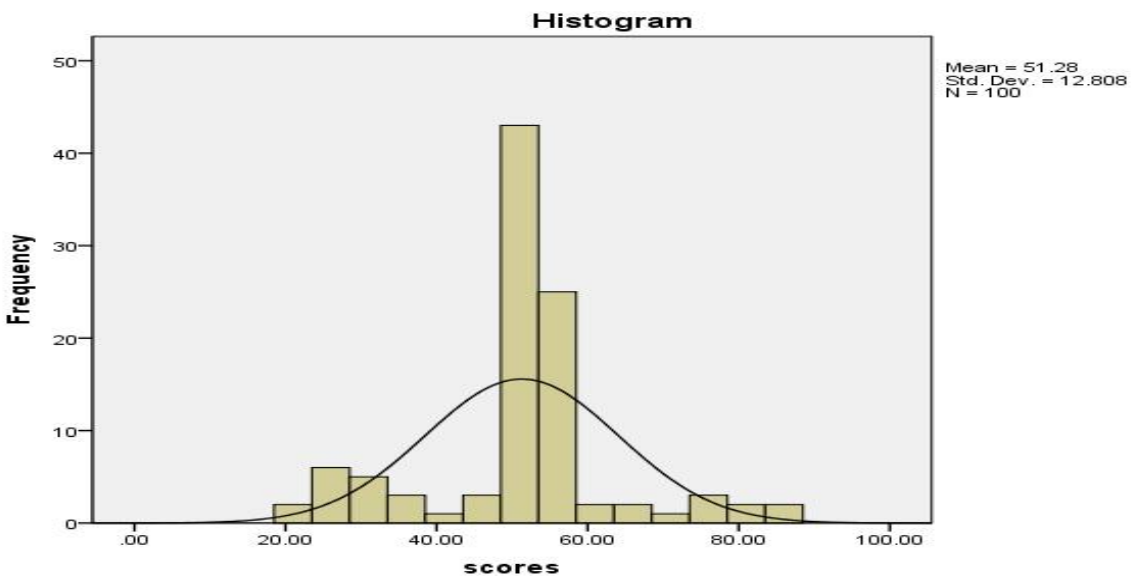

Figure1. Normal distribution of the homogenizing test

\subsection{Pretest}

The researcher administered a pre-test of writing concerning content knowledge to evaluate the students and come to future conclusions and decisions. The data (Table 4) revealed the mean and standard deviation of two groups regarding content knowledge. It was observed that the mean for the experimental group was 13.08 and the mean for the control group was 13.16 with the standard deviation of 3.10 and 3.17 , respectively.

Table 4. Pretest descriptive statistics

\begin{tabular}{cccccc}
\hline & group & $\mathrm{N}$ & Mean & Std. Deviation & $\begin{array}{c}\text { Std. Error } \\
\text { Mean }\end{array}$ \\
\hline Pretest & experimental & 40 & 13.0875 & 3.10683 & .49123 \\
& control & 40 & 13.1625 & 3.17116 & .50140 \\
\hline
\end{tabular}

To compare two groups systematically, an independent t-test was run in order to determine whether or not there were statistically significant differences between two groups in terms of their content knowledge. The result is displayed in Table 5.

Table 5. Pre independent t-test for both groups in terms of content knowledge

\begin{tabular}{|c|c|c|c|c|c|c|c|c|c|}
\hline & $\begin{array}{l}\text { Lever } \\
\text { for Eq } \\
\text { Var }\end{array}$ & $\begin{array}{l}\text { Test } \\
\text { lity of } \\
\text { ces }\end{array}$ & & & & est for Equa & y of Means & & \\
\hline \multirow[t]{2}{*}{$\begin{array}{c}\text { Pretest } \\
\text { Experimental } \\
\text { Control }\end{array}$} & \multirow[t]{2}{*}{$\mathrm{F}$} & \multirow[t]{2}{*}{ Sig. } & \multirow[t]{2}{*}{$\mathrm{t}$} & \multirow[t]{2}{*}{$\mathrm{df}$} & \multirow[t]{2}{*}{$\begin{array}{l}\text { Sig. }(2- \\
\text { tailed) }\end{array}$} & \multirow[t]{2}{*}{$\begin{array}{c}\text { Mean } \\
\text { Difference }\end{array}$} & \multirow[t]{2}{*}{$\begin{array}{l}\text { Std. Error } \\
\text { Difference }\end{array}$} & \multicolumn{2}{|c|}{$\begin{array}{l}95 \% \text { Confidence } \\
\text { Interval } \\
\text { of the Difference }\end{array}$} \\
\hline & & & & & & & & Lower & Upper \\
\hline $\begin{array}{c}\text { Equal variances } \\
\text { assumed }\end{array}$ & .097 & .756 & -.107 & 78 & .915 & -.07500 & .70194 & $\begin{array}{c}- \\
1.47245\end{array}$ & 1.32245 \\
\hline $\begin{array}{c}\text { Equal variances } \\
\text { not assumed }\end{array}$ & & & -.107 & $\begin{array}{c}77.9 \\
67\end{array}$ & .915 & -.07500 & .70194 & $\begin{array}{c}- \\
1.47246\end{array}$ & 1.32246 \\
\hline
\end{tabular}

As seen in Table 3, initially, two groups were not significantly different since at 0.05 level of significance for 78 degrees of freedom the sig. 2-tailed is 0.915 which is higher than 0.005 . In other words, data partially showed that the writing ability of two groups, in terms of content, was not so different and two groups were comparable at the onset of the study. 


\subsection{Posttest}

This part of the data analysis focuses on the difference between the performances of two groups to see whether the treatment had any effect on the posttest of the participants. As is presented in Table 6, the mean of the control group on their posttest was (12.36), having a standard deviation of (3.21), while the mean of experimental group was (14.36) with the standard deviation of (2.89).

Table 6. Posttest descriptive statistics

\begin{tabular}{cccccc}
\hline & group & $\mathrm{N}$ & Mean & Std. Deviation & $\begin{array}{c}\text { Std. Error } \\
\text { Mean }\end{array}$ \\
\hline Posttest & experimental & 40 & 14.3625 & 2.89559 & .45783 \\
& control & 40 & 12.3625 & 3.21851 & .50889 \\
\hline
\end{tabular}

Although the means of two groups clearly showed the difference, an independent t-test was run to ensure whether these groups have had any significant difference or not.

An independent t-test (Table 7) showed at 0.05 level of significance for 78 degrees of freedom the sig. 2-tailed is 0.003 which is lower than 0.005 , and therefore the existing difference is statistically significant. The null hypothesis that there is no difference between two groups after the treatment was rejected. The research question was answered that there was an enhancement in the content of the experimental group writing, utilizing a multimedia package containing both L1 and L2 manipulative and task-based activities.

Table 7. Post independent t-test for both groups in terms of content

\begin{tabular}{|c|c|c|c|c|c|c|c|c|c|}
\hline \multirow{3}{*}{$\begin{array}{c}\text { Posttest of } \\
\text { Experimental \& } \\
\text { Control }\end{array}$} & \multicolumn{2}{|c|}{$\begin{array}{c}\text { Levene's Test for } \\
\text { Equality of } \\
\text { Variances }\end{array}$} & \multicolumn{7}{|c|}{ t-test for Equality of Means } \\
\hline & \multirow[t]{2}{*}{$\mathrm{F}$} & \multirow[t]{2}{*}{ Sig. } & \multirow[t]{2}{*}{$\mathrm{t}$} & \multirow[t]{2}{*}{$\mathrm{df}$} & \multirow[t]{2}{*}{$\begin{array}{l}\text { Sig. (2- } \\
\text { tailed) }\end{array}$} & \multirow[t]{2}{*}{$\begin{array}{c}\text { Mean } \\
\text { Difference }\end{array}$} & \multirow[t]{2}{*}{$\begin{array}{l}\text { Std. Error } \\
\text { Difference }\end{array}$} & \multicolumn{2}{|c|}{$\begin{array}{l}\text { 95\% Confidence } \\
\text { Interval } \\
\text { of the Difference }\end{array}$} \\
\hline & & & & & & & & Lower & Upper \\
\hline $\begin{array}{l}\text { Equal variances } \\
\text { assumed }\end{array}$ & .104 & .748 & 2.922 & 78 & .003 & 2.00000 & .68453 & .63720 & 3.36280 \\
\hline $\begin{array}{l}\text { Equal variances } \\
\text { not assumed }\end{array}$ & & & 2.922 & 77.144 & .003 & 2.00000 & .68453 & .63697 & 3.36303 \\
\hline
\end{tabular}

\subsection{The subsidiary findings}

Since the study's focal point was on content knowledge in writing, the study provided a chance to work on this issue in more detail such as: Checking the rate of progress within each experimental and control group classes in terms of content from pretest to posttest. Although this was not the main discussion of the study, it was related to writing and hence worthy of consideration. The mean of experimental group in their pretest and posttest were (13.08) and (14.36) respectively. It was observed that, regarding the content knowledge, the experimental group enhanced significantly after the treatment. To measure the effects of the treatment on the experimental group or observe whether the difference between their performances on the pretest and the posttest was significant or not, a paired t-test was run.

Table 8 shows that after the treatment, a significant change was observed in content of written products of the experimental group. The results tended to show that there was a significant difference between their performance on the pretest and the posttest. The post independent t-test (table 8 ) at the significant level of 0.05 for 39 degrees of freedom the sig. 2-tailed is 0.000 which is lower than 0.005 , and therefore the existing difference is statistically significant. This significant difference can demonstrate the impact of the treatment, enhancing content knowledge by means of a multimedia, on the writers.

Table 8. Paired t-test results of the experimental group in terms of content

\begin{tabular}{ccccccccc}
\hline & \multicolumn{9}{c}{ Paired Differences } \\
\cline { 2 - 5 } Experimental group & Mean & $\begin{array}{c}\text { Std. } \\
\text { Deviation }\end{array}$ & $\begin{array}{c}\text { Std. } \\
\text { Error } \\
\text { Mean }\end{array}$ & $\begin{array}{c}95 \% \text { Confidence } \\
\text { Interval of the } \\
\text { Difference }\end{array}$ & t & df & Sig. (2-tailed) \\
\cline { 5 - 6 } $\begin{array}{c}\text { Pretest } \\
\text { \& } \\
\text { Posttest }\end{array}$ & -1.27500 & 1.37258 & .21702 & -1.71397 & -.83603 & -5.875 & 39 & .000 \\
\hline
\end{tabular}


This part of peripheral investigation tries to measure content knowledge of the control group's writings. It was observed that participants in this group did not improve in terms of content. The content knowledge of the control group after 12 sessions of study numerically decreased (from 13.16 to 12.36). To observe whether the difference between the performances of the control group participants on pretest and posttest regarding content was significant or not, a paired t-test was run.

The result of paired t-test of control group showed that, considering content, this group did not show any changes after the twelve weeks of study, since the post independent t-test (Table 9) at the significant level of 0.05 for 39 degrees of freedom the sig. 2-tailed is 0.115 which is higher than 0.005 , and therefore the existing difference is not statistically significant.

Table 9. Paired t-test results of the control group in terms of content

\begin{tabular}{|c|c|c|c|c|c|c|c|c|}
\hline \multirow{3}{*}{ Control group } & \multicolumn{5}{|c|}{ Paired Differences } & \multirow{3}{*}{$\mathrm{t}$} & \multirow{3}{*}{$\mathrm{df}$} & \multirow{3}{*}{ Sig. (2-tailed) } \\
\hline & \multirow[t]{2}{*}{ Mean } & \multirow[t]{2}{*}{$\begin{array}{c}\text { Std. } \\
\text { Deviation }\end{array}$} & \multirow{2}{*}{$\begin{array}{l}\text { Std. } \\
\text { Error } \\
\text { Mean }\end{array}$} & \multicolumn{2}{|c|}{$\begin{array}{l}95 \% \text { Confidence } \\
\text { Interval of the } \\
\text { Difference }\end{array}$} & & & \\
\hline & & & & Lower & Upper & & & \\
\hline \multicolumn{9}{|l|}{ Pretest } \\
\hline$\&$ & .80000 & 1.03651 & 16389 & .46851 & 1.13149 & 1.931 & 39 & .115 \\
\hline Posttest & & & & & & & & \\
\hline
\end{tabular}

\section{Discussion}

In response to the research questions, it would appear from the evidence here that the recommended pattern for enhancing content knowledge by a multimedia package, a CD containing recordings both in L1 and L2 manipulative as well as task-based activities, is superior to the only exposure of learners to current-traditional rhetoric approach pattern regarding writing content. A plausible explanation concerning the observation of this improvement can be the task itself since the nature of the task was quite different from the traditional way the participants were used to. That is, writing products benefited from the content knowledge.

The former findings about content, as Urquhart and Weir (1998) believe, have provided a considerable amount of experimental evidence that familiarity with content has a significant effect on the performance. As Hedge (2000), for example, stated, "Good writers concentrate on the overall meaning, organization and content of a text, etc." (p. 305). As concluded in this research, the writing product benefits through using the recommended multimedia package, a CD containing both L1 and L2 manipulative and task-based activities. By focusing on content, linguistic skills find their right place as means for students to communicate, which does not let the language get disconnected or be artificial. As a result, students are able to learn better and faster because they are surrounded by real language (Blanton, 1992). According to Blanton, vocabulary and linguistic forms develop along with the content knowledge development. As content expands, a context for weaving together the knowledge and insights from different sources develop, which here in this study was by means of class discussions, printed texts and the audio part of the material. Along with Blanton's study that students need to work with complete texts as opposed to disconnected paragraphs and unrelated exercises, the drills involved in this study's material contributed the students to produce better-written texts.

Moreover, the recent impact of technology on writing has certainly not gone unnoticed since its development. The results of a study by Adair-Hauck, Willingham-McLain, and Youngs (1999) on the effect of using technology indicated an enhancement in language learning on the performance of college-level students in writing, which is similar to the findings of this study. Apparently, there are certain factors that lead to a more effective writing product. Studies (Underwood \& Brown, 1997; Bowyer \& Blanchard, 2003) corroborated that multimedia environments and visual contexts at macro-level can generate an increased motivation in learners. Indeed, the "novelty" of a multimedia package at macro-level (particularly in EFL contexts) can generate an increased motivation in learners. This increased motivation might lead to increased levels of attention. It could be claimed that the improvement observed in the experimental class in this study was to some extent due to the increasing level of attention on the macro structures and vocabularies.

Like any other researches, the shortcomings of the study that could not be controlled included the fact that firstly among the participants, who were all at the intermediate level of proficiency, the number of females exceeded the males (75\%).Secondly, the participants were not of the same age; it was not a variable in this study. Thirdly, the classes were self-selected by the students according to the time and number of classes offered; as a result, the number of participants was limited to two classes with 80 of 100 students who took the essay writing course.

Applying a multimedia package in instruction can help students become more involved in the teaching-learning process, and assist them in expressing their ideas. Johnstone and Milne (1995) stated that the use of a teacher-controlled 
multimedia tool increased the amount of communicative discourse in the classroom by both teachers and students. It can be claimed that the multimedia itself can be strong enough to affect learners' performance on all components of writing, so the role of a multimedia may not be underestimated. Based on the findings of this research, though, such multimedia package can help learners with writing regarding their content knowledge. For those learners who find writing a difficult task because they cannot organize what they know or do not have much information about a given topic, what is here called a multimedia package can be mainly helpful.

Enhancing content knowledge in writing, if included in educational schedules, like reading, might empower the learners with an insight into the language they are learning. In addition, it provides a means of self-expression different from what is common in writing classes. Students in traditional classes complain about the tedious and monotonous English writing classes and the fact that they want something new and different (Carter \&Nunan, 2001). As a result of this freedom in multimedia classes, they may enjoy writing which has been 'frustrating' for them. Very broadly put, in content writing enhancement class, by the use of a multimedia package, the learners no longer worry what to write about as those in traditional essay writing classes. This way, essay writing through using a multimedia package (a CD containing both L1 and L2 manipulative and task-based activities) for content knowledge improvement can be used as a substitute in formal writing classes or as an activity in students' leisure time since Berhof (1981) believes students learn more when they write more and freely. So, enhancing content knowledge in writing tends to foster language learning.

Another research may investigate the role or probable interaction of gender on the performance of both groups since the number of female exceeded in this study. The effect of a multimedia package on other aspects of the written products, such as cohesion and coherence, can be investigated in another study. It would be interesting to investigate the effect of age on the content knowledge of the language learners. Another study may be conducted to explore the impact of a multimedia package on the improvement of the other language skills, listening, reading, speaking as well as other language components or even on the impact of a multimedia package on promoting the motivation and attitude of EFL learners toward the writing skill. Time can be another variable and a carefully planned longitudinal study may not confirm the findings of this study because the participants took part in this study for just one semester. Further research studies could investigate whether this stratagem i.e. enhancing content knowledge through the use of a multimedia package (a CD containing both L1 and L2 manipulative and task-based activities) can have any specific effect on students' creativity while they are writing essays on the topics different from those they already worked on.

\section{Acknowledgement}

My first debt of gratitude is to my friend and colleague, Mr. Amin Davari whose detailed comments and guidance all through the way gave me invaluable insights that I incorporated into my article. I would be amiss if I did not thank my family and friends who provided me with encouragement and support to finish this job specially Ms. Bahare Molazem who assisted me through writing and proof reading the article.

\section{References}

Acha, J. (2009). The effectiveness of multimedia programs in children's vocabulary learning. BJET, 40(1), 23-31.

Adair-Hauck, B., Willingham-McLain, L., \& Earnest-Youngs, B. (1999).Evaluating the integration of technology and second language learning. CALICO Journal, 17(2), 269-306.

Alderson, J. C., \&Urquhart, A. H. (1985).The effect of students' academic discipline on their performance on ESP reading tests. $L T J, 2(2), 192-204$.

Berhof, B. (1981).Moving toward aesthetic literacy in the first grade. In D. J. Leu\& C. K. Kinzer (Eds.), Examining central issues in literacy research, theory, and practice (pp. 217-233). Chicago: National Reading Conference.

Blanton, L. L. (1992). A holistic approach to college ESL: Integrating language and content. JELT, 46(3), $285-293$.

Bowyer, P. K. \& Blanchard, C.L. (2003). Multimedia based enhancement of the science of technology in the distance education learning environment. AJET, 19(3), 323-338.

Carter, R., \&Nunan, D. (2001).The Cambridge guide to teaching English to speakers of other languages.UK: Cambridge University Press.

Chastain, K. (1988).Developing second language skills: Theory and practice. Orlando, FL: Harcourt Brace Jovanovich.

Gao. H. Z. (2005). The feasibility and necessity of using multi-media computer to assist foreign language teaching. Unpublished master's thesis, Liaoning Normal University, Liaoning, China.

Graham, S., \& Perin, D. (2007a).A meta-analysis of writing instruction for adolescent students. JEDP, 99 (3), $445-476$.

Graham, S., \& Perrin, D. (2007b).Writing next: Effective strategies to improve writing of adolescents in middle and high schools. Washington, DC: Alliance for Excellence in Education.

Hedge, T. (2000).Teaching and learning in language classroom. New York: Oxford University Press.

Hillocks, G. (1986).Research on written composition: New directions for teaching. Urbana, IL: National Council of Teachers of English.

Howard, D.V. (1983). Cognitive psychology. New York: Macmillan Publishing. 
Huot, B. (1990). The literature of direct writing assessment: major concerns and prevailing trends. Review of Educational research, 60, 237-263.

Hyland, K. (2002). Genre-based pedagogies: A social response to process. JSLW, 12, 17-29.

Jacobs, H.L., Zinkgraf, S.A., Wormuth, D.R., Hartfiel, V.F., \&Hughey, B. (1981).Testing ESL composition: A practical approach. Rowley, Massachusetts: Newbury House Publishers.

Johnstone, J., \& Milne, L. (1995).Scaffolding second language communicative discourse with teacher-controlled multimedia. FLA, 28, 315-329.

Meisel, J., Clahsen, H. and Pienemann, M. (1981).On determining developmental stages in natural second language acquisition. Studies in Second Language Acquisition, 3, 109-35.

Morrison, G. R., \&Anglin, G. J. (2005). Research on cognitive load theory: Application to e-learning. ETR\& D, 53, 94104.

Pienemann, M. (1985).Learnability and syllabus construction. In K. Hyltenstam\& M. Pienemann (Eds.), Modeling and assessing second language acquisition (pp.23-76).Clevedon, Avon: Multilingual Matters.

Rutherford, W., \& Sharwood-Smith, M. (Eds.). (1988).Grammar and second language teaching. Rowley, MA: Newbury House.

Smith, S. M., \& Woody, P. C. (2000). Computer in teaching: Interactive effect of multimedia instruction and learning styles. TPJ, 27(3), 220-223.

Underwood, J., \& Brown, J. (1997). Integrated learning systems: Potential into practice. UK: Heineman.

Urquhart, A., \& Weir, C. (1998).Reading in a second language: Process, product and practice. London: Longman.

Vinson, L. L. N. (1980). The effects of two prewriting activities upon the overall quality of ninth graders' descriptive paragraphs. Unpublished doctoral dissertation, University of South Carolina-Columbia.

Wang, C. R. (2008). A comparative study on the traditional model of English teaching and multimedia computer aided English teaching. $H N F N C$, 8(3), 56-58.

Weir, C. (2005).Language testing and validation: An evidence-based approach. UK: Palgrave Macmillan. http://www.ets.org (accession date: 2010, Nov 19th). 